\title{
Food industry wastewaters and Nutrition, Dietetics \& Nutraceuticals
}

\author{
Ana R Prazeres ${ }^{1,2 *}$ \\ ${ }^{1}$ Centro de Biotecnologia Agrícola e Agro-Alimentar do Alentejo (CEBAL)/Instituto Politécnico de Beja (IPBeja), 7801-908 Beja, Portugal \\ ${ }^{2}$ Instituto de Ciências Agrárias e Ambientais Mediterrânicas (ICAAM), Universidade de Évora, Pólo da Mitra, Apartado 94, 7006-554 Évora, Portugal \\ ${ }^{*}$ Corresponding author: Ana R Prazeres, Centro de Biotecnologia Agrícola e Agro-Alimentar do Alentejo (CEBAL)/Instituto Politécnico de Beja (IPBeja), Beja, Portugal; \\ E-mail: ana.prazeres@cebal.pt; anaritaprazeres@gmail.com; anaritaprazeres2@gmail.com
}

Received: November 23, 2019; Accepted: November 28, 2019; Published: December 01, 2019

\section{Editorial}

I am pleased to present the inaugural issue of the journal of Nutrition, Dietetics \& Nutraceuticals (NDN) from the open access international publishing house Research Open World. NDN provides a platform covering in an interdisciplinary manner all areas of Nutrition, Dietetics \& Nutraceuticals. The goal of NDN is to publish actual, original and high-quality research articles, reviews, and short communications, which can be divided into three categories: The science of nutrition, Community Nutrition and Therapeutic nutrition and dietetics.

Specific studies and developments of interest for the journal comprise Nutrition and Food Sciences and Food Biotechnology. Food industry uses extensively a high quantity of water in the industrial processes, namely, heating and cooling systems and washing of equipment and facilities. Consequently, it produces a large quantity of problematic wastewaters. Food industry wastewaters constitute a complex subject for the environment and public health due to the presence of high concentrations of organic matter monitored by chemical oxygen demand (COD), biochemical oxygen demand (BOD) and total organic carbon (TOC), salinity (high conductivity values), total and suspended solids and nutrients (calcium, magnesium, phosphorus, potassium, sodium and chloride). Food industry wastewater can be responsible for soil contamination, accumulation of toxic compounds in ecosystems, eutrophication phenomena, rapid oxygen depletion, and surface and groundwater contamination. Within this type of wastewater, it can be highlighted the dairy, winery, slaughterhouse and olive oil mill wastewater. However, appropriate and innovative treatment processes are required. Conventional treatment processes of food industry wastewaters are based on biological principles, for instance, aerobic [1,2] and anaerobic [3] digestion and wetlands [4]. However, these biological processes have some limitations. Several physicochemical processes have been applied in order to reduce organic and inorganic contamination, for example, coagulation-flocculation with $\mathrm{FeSO}_{4}, \mathrm{Al}_{2}\left(\mathrm{SO}_{4}\right)_{3}$, and $\mathrm{FeCl}_{3}$ for cheese whey wastewater [2] and winery wastewater [5], coagulation with chitosan, starch, alum and ferric chloride for olive oil wastewater [6], acid precipitation with $\mathrm{H}_{2} \mathrm{SO}_{4}, \mathrm{HNO}_{3}$ and $\mathrm{HCl}$ for cheese whey and slaughterhouse wastewater $[7,8]$, basic precipitation with $\mathrm{NaOH}$ and $\mathrm{Ca}(\mathrm{OH})_{2}$ for cheese whey wastewater $[9,8]$, oxidation with $\mathrm{Ca}(\mathrm{ClO})_{2}, \mathrm{H}_{2} \mathrm{O}_{2}$ and $\mathrm{CaO}_{2}$ for slaughterhouse wastewater [7], Fenton-like oxidation system for pretreated cheese whey wastewater [10], ozone-based advanced oxidation processes $\left(\mathrm{O}_{3}, \mathrm{O}_{3} / \mathrm{UV}\right.$ and $\mathrm{O}_{3} / \mathrm{UV} / \mathrm{H}_{2} \mathrm{O}_{2}$ ) for winery wastewater [11], photocatalytic/photolytic reactor system for winery wastewater [12], solar photochemical for winery wastewater [13], electrochemical advanced oxidation [14] and solar driven advanced oxidation [15] for the pretreated winery wastewater, use of clay-polymer nano composites for olive oil mill and winery wastewater [16], reverse osmosis for winery wastewater [17], electrolysis system for olive oil mill wastewater [18], electrocoagulation for olive oil mill wastewater [19] and slaughterhouse wastewater [20], Fenton's Reagent for olive oil mill wastewater [21], conductive-diamond electrooxidation (CDEO), ozonation and Fenton oxidation for olive oil mill wastewater [22] and alkaline and enzymatic hydrolysis for slaughterhouse wastewater [23]. The application of these effluents on the soil can also be an alternative [24, 25]. However, some precautions should be taken when these effluents are applied at long-term. Thus, NDN can receive important works in the area of biological and physicochemical treatment, recovery and reuse of the food industry wastewaters.

Thank you for your contribution to the Journal of Nutrition, Dietetics \& Nutraceuticals

Sincerely,

Ana R. Prazeres

\section{Acknowledgments}

The author thanks to the Alentejo Regional Operational Program (ALENTEJO 2020, Portugal 2020) for the financing of the HYDROREUSE project - Treatment and reuse of agro-industrial wastewater using an innovative hydroponic system with tomato plants (ALT20-03-0145-FEDER-000021), through the Regional Development European Fund (FEDER).

\section{References}

1. Petruccioli M, Duarte JC, Eusebio A, Federici F (2002) Aerobic treatment of winery wastewater using a jet-loop activated sludge reactor. Process Biochemistry 37: $821-829$.

2. Rivas J, Prazeres AR, Carvalho F, Beltrán F (2010) Treatment of Cheese Whey Wastewater: Combined Coagulation-Flocculation and Aerobic Biodegradation. Journal of Agricultural and Food Chemistry 58: 7871-7877. [crossref] 
3. Yu H, Zhu Z, Hu W, Zhang $\mathrm{H}$ (2002) Hydrogen production from rice winery wastewater in an upflow anaerobic reactor by using mixed anaerobic cultures. International Journal of Hydrogen Energy 27: 1359-1365.

4. Serrano L, de la Varga D, Ruiz I, Soto M (2011) Winery wastewater treatment in a hybrid constructed wetland. Ecological Engineering 37: 744-753.

5. Braz R, Pirra A, Lucas MS, Peres JA (2010) Combination of long term aerated storage and chemical coagulation/flocculation to winery wastewater treatment. Desalination 263: 226-232.

6. Meyssami B, Kasaeian AB (2005) Use of coagulants in treatment of olive oil wastewater model solutions by induced air flotation. Bioresource Technology 96 : 303-307. [crossref]

7. Prazeres AR, Fernandes F, Madeira L, Luz S, Albuquerque A et al. (2019) Treatment of slaughterhouse wastewater by acid precipitation $\left(\mathrm{H}_{2} \mathrm{SO}_{4}, \mathrm{HCl}\right.$ and $\left.\mathrm{HNO}_{3}\right)$ and oxidation $\left(\mathrm{Ca}(\mathrm{ClO})_{2}, \mathrm{H}_{2} \mathrm{O}_{2}\right.$ and $\left.\mathrm{CaO}_{2}\right)$. Journal of Environmental Management 250. [crossref]

8. Prazeres AR, Luz S, Fernandes F, Jerónimo E (2019) Cheese wastewater treatmen by acid and basic precipitation: application of $\mathrm{H}_{2} \mathrm{SO}_{4}, \mathrm{HNO}_{3}, \mathrm{HCl}, \mathrm{Ca}(\mathrm{OH})_{2}$ and $\mathrm{NaOH}$. Journal of Environmental Chemical Engineering. In Press.

9. Rivas J, Prazeres AR, Carvalho F (2011) Aerobic Biodegradation of Precoagulated Cheese Whey Wastewater. Journal of Agricultural and Food Chemistry 59: 25112517. [crossref]

10. Prazeres AR, Carvalho F, Rivas J (2013) Fenton-like application to pretreated cheese whey wastewater. Journal of Environmental Management 129: 199-205. [crossref]

11. Lucas MS, Peres JA, Puma GL (2010) Treatment of winery wastewater by ozonebased advanced oxidation processes $\left(\mathrm{O}_{3}, \mathrm{O}_{3} / \mathrm{UV}\right.$ and $\left.\mathrm{O}_{3} / \mathrm{UV} / \mathrm{H}_{2} \mathrm{O}_{2}\right)$ in a pilotscale bubble column reactor and process economics. Separation and Purification Technology 72: 235-241.

12. Agustina TE, Ang HM, Pareek VK (2008) Treatment of winery wastewater using a photocatalytic/photolytic reactor. Chemical Engineering Journal 135: 151-156.

13. Lucas MS, Mosteo R, Maldonado MI, Malato S, Peres JA (2009) Solar Photochemical Treatment of Winery Wastewater in a CPC Reactor. Journal of Agricultural and Food Chemistry 57: 11242-11248.

14. Moreira FC, Boaventura RA, Brillas E, Vilar VJ (2015) Remediation of a winery wastewater combining aerobic biological oxidation and electrochemical advanced oxidation processes. Water Research 75: 95-108. [crossref]
15. Souza S, Moreira FC, Dezotti MWC, Vilar VJP, Boaventura RAR (2013) Application of biological oxidation and solar driven advanced oxidation processes to remediation of winery wastewater. Catalysis Today 209: 201-208.

16. Rytwo G, Lavi R, Rytwo Y, Monchase H, Dultz S et al. (2013) Clarification of olive mill and winery wastewater by means of clay-polymer nanocomposites. Science of The Total Environment 442: 134-142. [crossref]

17. Ioannou LA, Michael C, Vakondios N, Drosou K, Xekoukoulotakis NP et al. (2013) Winery wastewater purification by reverse osmosis and oxidation of the concentrate by solar photo-Fenton. Separation and Purification Technology 118: 659-669.

18. Israilides CJ, Vlyssides AG, Mourafeti VN, Karvouni G (1997) Olive oil wastewater treatment with the use of an electrolysis system. Bioresource Technology 61: 163170 .

19. Inan H, Anatoly Dimoglo, Şimşek H, Karpuzcu M (2004) Olive oil mill wastewater treatment by means of electro-coagulation. Separation and Purification Technology 36: $23-31$.

20. Asselin M, Drogui P, Benmoussa H, Blais JF (2008) Effectiveness of electrocoagulation process in removing organic compounds from slaughterhouse wastewater using monopolar and bipolar electrolytic cells. Chemosphere 72: 1727 1733.

21. Rivas FJ, Beltrán FJ, Gimeno O, Frades J (2001) Treatment of Olive Oil Mill Wastewater by Fenton's Reagent. Journal of Agricultural and Food Chemistry 49: 1873-1880. [crossref]

22. Cañizares P, Lobato J, Paz R, Rodrigo MA, Sáez C (2007) Advanced oxidation processes for the treatment of olive-oil mills wastewater. Chemosphere 67: 832838

23. Masse L, Kennedy KJ, Chou S (2001) Testing of alkaline and enzymatic hydrolysis pretreatments for fat particles in slaughterhouse wastewater. Bioresource Technology 77: 145-155. [crossref]

24. Prazeres AR, Carvalho F, Rivas J, Patanita M, Jóse Dôres (2013) Growth and development of tomato plants Lycopersicon Esculentum Mill. under different saline conditions by fertirrigation with pretreated cheese whey wastewater. Water Science and Technology 67: 2033-2041. [crossref]

25. Sierra J, Martí E, Montserrat G, Cruañas R, Garau MA (2001) Characterisation and evolution of a soil affected by olive oil mill wastewater disposal. Science of The Total Environment 279: 207-214.

\section{Citation:}

Ana R Prazeres (2019) Food industry wastewaters and Nutrition, Dietetics \& Nutraceuticals. Nutr Diet Nutraceuticals 1(1): 1-2. 